\title{
MODELING THE INVESTMENT ACTIVITIES IN THE COMPANY
}

\section{IRINA ANATOLIEVNA KISELEVA, MIKHAIL SAMUILOVICH GASPARIAN, MIKHAIL VLADIMIROVICH KARMANOV, VLADIMIR IVANOVICH KUZNETSOV \& NATALIA ALEKSEEVNA SADOVNIKOVA}

\author{
Plekhanov Russian University of Economics, 36 Stremyanny Lane, Moscow, 117997, Russian Federation
}

The world experience of the leading companies indicates that successful development of a firm and improvement of its performance are impossible without a properly formulated strategy as a set of measures aimed at achieving a goal. The relevance of this work lies in the fact that the activities of any enterprise are accompanied by risks, due to which a need arises to formulate and apply an investment strategy within the competencies of various departments. The modern business is conducted in the conditions of fierce competition; a deep, comprehensive assessment of the situation and a reliable forecast of development are required to make adequate decisions. The main stages of the investment activities of the company have been defined, possible alternatives to the strategic choice have been identified, indicators of investment project performance have been determined, and investment models have been proposed. The methods used in the work include the methods of cognition, retrospective and documentary analysis, as well as synthesis, generalization, and systematization.
\end{abstract}

KEYWORDS: Company, Model, Investment, Risk, Risk Management, Investment Project

Received: Jun 03, 2020; Accepted: Jun 23, 2020; Published: Jul 24, 2020; Paper Id.: IJMPERDJUN2020444

\section{INTRODUCTION}

In any field of business, outcome depends on the availability and efficiency of using the investment activities of the enterprise $[1,2,3]$. Therefore, concern about investments is the starting point and the end result of the activities for any economic agent. These issues are of paramount importance in the market economy. The task of investment design is to provide all the possible details, influencing factors, and development options for the project, to prepare the project team for its implementation, to understand the capabilities and feasibility of the project, and to see the ways of its implementation. At the current stage of business development, in the period of growth in investment activities, when growing risks make it difficult to take decisions regarding possible areas of financing, the issues of rational risk management and of choosing a model for assessing the acceptable risk level are especially relevant.

In a broad sense, investment activities are the activities related to investing in order to generate income (effect). A similar interpretation is contained in the Law "On investment activities in the Russian Federation conducted as capital investments", according to which investment activities are understood as investing and practical actions aimed at making a profit and (or) achieving another useful effect. In the narrow sense, investment activities or just investing is a process of converting investment resources into investments $[4,5,6]$.

Investment activities are carried out in two stages:

- Accumulating funds for investment, i.e., forming investment resources; and 
- Investing the accumulated funds (investment resources) in specific objects (areas), which secure income on these investments.

Investment activities are a special type of the enterprise activities. They have the following main specifics that distinguish them from other types of the enterprise activities [5].

Firstly, investment activities are the main means of ensuring the growth of the current performance, contributing to the successful achievement of the strategic goals of the enterprise, which, in turn, depending on the specific areas of investment, can be achieved either by increasing operating income as a result of growth in production and sales, or by decreasing current unit costs due to the timely replacement of outdated and obsolete equipment and technology for its production techniques.

Secondly, it is the unevenness of investment activities and substantial lagging (especially in the case of real investment) in obtaining the investment effect from the period (moment) of investment, i.e., the formation of the so-called "lag".

Thirdly, investment activities, in contrast to other types of enterprise activities, are described by a rather high level of risk called "investment risk" $[7,8]$.

\section{METHODS}

A properly built model of investment activities will allow the management to answer a number of important questions:

- What will happen in certain conditions?

- Which of the options to choose?

- What are the possible consequences of the influence if the circumstances can be influenced (external factors)?

- How much will be earned (if any) if the external factors cannot be influenced?

- Is it worth conducting any business at all under the certain parameters of the markets and the external environment?

No model can exist without indicators because no control can exist without measurements, and the model is required for management. Any model works with indicators and consists of three interconnected parts (Figure 1).

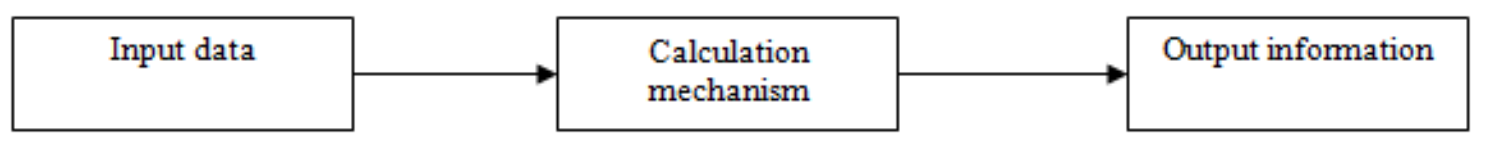

Figure 1: Example of a Model with Indicators.

- Input sets the input (source) data in a specific format (preferably compatible with the external environment).

- Calculation mechanism contains the relationship between the input data and the target estimates (preferably deriving target estimates from the input data with the maximum accuracy and speed).

- Output provides the end user with target estimates in a certain form (preferably the most convenient one).

Several classes of models can be distinguished, according to the purpose and approach to modeling: resource, estimate, scenario, organizational, financial, and complex $[9,10]$. 
Some of the most popular forecasting methods are commonly called time series models. These models use historical data to predict future demand. This forecasting method is especially important for the objects that are constantly ordered, since these methods can be "automated" in computer information systems to a large extent.

Models suggest that each observed point of the demand data consists of a systematic component and a random component. The time series model is designed to forecast a systematic component, but not a random component [11, p. 42]. The idea is similar to the logic of quality control diagrams in the sense that no attempts should be made to respond to variability of the process if it is within control. A response (or a change in the forecast model) due to random errors is likely to increase the error in future forecasts. One must try to forecast the range or variation of this random error. Models can be designed for almost any type of systematic change in demand, but there is a real danger for forecasting the random component $[12,13]$.

Forecasts are always erroneous, but some of them are "more erroneous" than others. Forecasting the demand for innovative products and fashionable goods is usually more complicated than forecasting the demand for more "commodity" products that are sold daily. Aggregate forecasts of a group of similar products are usually more accurate than individual forecasts of individual products included in the group. Finally, the longer the forecast is in the future, the less reliable the forecast will be.

However, commodity-like products, which are sold daily, are much more suitable for quantitative models and require very little judgment to forecast demand. Nevertheless, when knowledge of certain events leads to thinking that future demand may not keep track of historical trends, some judgments can be made in order to adjust the models that use historical data.

Since forecasts are never accurate, two common solutions are often offered to "adjust" forecast errors [14, 15].

Firstly, it is reducing the execution time to respond to changes more quickly. This is a good partial solution, but reducing the execution time is not always easy to make and often expensive. In addition, reducing the execution time in many cases simply transfers problems from one part of the supply chain to another.

Secondly, it is "placing an order" so that the inventory is not produced before demand arises. This solution is also good, but like reducing the execution time, it tends to shift demand to the next level of the supply chain. In addition, custom production still requires forecasts in order to be able to store the right quantities of raw materials at hand. Therefore, although these ideas help improve some aspects of the forecasting problem, they do not eliminate the need for some forecasting methods. Collaboration is a more recent proposal to correct forecast errors. The idea is that if different parts of the supply chain collaborate according to a common forecast and all plans are based on that single forecast, there is no need for one part of the chain to be hedged based on the uncertainty of what occurs in the other parts.

The intercompany collaboration will be commonplace; it seems that a little common sense will dictate that everyone in the firm comes along with a common set of forecasted figures. However, this rarely happens. Marketing has many forecasts, and so do operations.

The goals of any enterprise, regardless of ownership, are to obtain financial benefits and to build up economic potential. Investments are a tool to achieve these goals, but each investment decision must be based on the results of investment analysis in order to be successful. 
The assessment of the economic efficiency of investments serves as a basis for making investment decisions. The concept of the efficiency of an investment project is often based on the degree of its compliance with the goals and interests of investment participants $[16,17,18]$.

The purpose of assessing investment projects is a comprehensive answer to three basic questions: what the return on investment is, what the payback periods of the project are, and what the risks of the project are. The proper investment assessment of the project allows to assess the real need for investment and the availability of the conditions required for this, to choose the best investment solutions, to identify factors that can influence the actual results of investment and adjust their effect, to evaluate acceptable risk and return parameters, and to develop measures for post-investment monitoring [19, p. 2376].

The investment performance indicators can be classified according to the following criteria [6]:

- By the type of a summarizing indicator that serves as a criterion of economic efficiency of investments:

- Absolute, where summarizing indicators are defined as the difference between the cost estimates of the outcome and the costs associated with the implementation of the project;

- Relative, where summarizing indicators are defined as the ratio of the cost estimates of the project outcome to the total cost of their receipt; and

- Temporal, which estimate the payback period of investment costs;

- By the method of comparing monetary costs and outcomes that are heterogeneous in time:

- Statistical, where cash flows arising at different points in time are evaluated as equivalent; and

- Dynamic, where cash flows resulting from the project implementation are reduced to an equivalent basis by discounting and ensuring the comparability of cash flows that are heterogeneous in time.

Statistical methods are also called methods based on accounting estimates, and dynamic methods are called methods based on discounted estimates.

Statistical estimation methods. They are also known as simple or traditional, developed back in the Soviet times. They are still relevant today, since, being very simple to implement, at the same time they allow to get a clear picture of the investment effectiveness, especially at the first stage of estimation [20].

\section{PP}

The payback period $(P P)$ is the most common statistical indicator for evaluating investment projects.

The payback period is understood as a period of time from the moment the project is launched till the object commissioning, when the operating income becomes equal to the initial investment (capital costs and operating costs).

This indicator allows answering the following question: when will the invested capital fully repay? The economic meaning of the indicator is to determine the period after which the investor can return the invested capital.

To calculate the payback period, the elements of the payment series are summed up on an accrual basis, forming the accumulated flow balance, until the amount becomes positive. The ordinal number of the planning interval, in which 
the accumulated flow balance becomes positive, indicates the payback period expressed in planning intervals. A fractional number is rounded up to the nearest integer.

\section{NPV}

The net present value is found as the difference between the discounted cash flows of income and the expenses incurred in the course of the investment implementation for the forecast period.

The idea of the criterion is to compare the present value of future cash receipts from the project implementation with the investment costs required for its implementation.

The method involves the sequential passage of the following stages:

- Calculating the cash flow of the investment project;

- Selecting a discount rate that takes into account the return on alternative investments and the risk of the project; and

- Finding the net present value.

The conditions for making an investment decision based on this criterion are as follows:

- If NPV > 0, then the project should be accepted;

- If NPV < 0, then the project should be rejected; and

- If NPV $=0$, then the project will bring neither profit nor loss.

This method is based on following the main target determined by the investor - maximizing its final state or increasing the value of the firm. Following this target is one of the conditions for a comparative assessment of investments based on this criterion [21, 22].

The negative net present value indicates the inappropriateness of making decisions on financing and implementing the project because at NPV $<0$, the value of the company will decrease in case of the adoption of the project, i.e., the owners of the company will incur losses, and the main target will not be achieved.

The positive net present value indicates the feasibility of making decisions on the financing and implementing the project, and when comparing the investment options, the one with the highest NPV is considered preferable because at NPV $>0$, the value of the company, and therefore the well-being of its owners will increase in case of the adoption of the project. If NPV $=0$, then the project should be accepted if its implementation strengthens the flow of income from previously implemented capital investment projects. For example, expanding the parking lot by a hotel will increase the flow from real estate income.

\section{PI}

The profitability index (PI) is a relative indicator of the investment project effectiveness that describes the level of income per unit of cost, i.e., the efficiency of investments - the higher the value of this indicator is, the higher the return on the monetary unit invested in this project will be. This indicator should be preferred when collecting the investment portfolio in order to maximize the total NPV. 
The conditions for the adoption of the project by this investment criterion are as follows:

- $\quad$ If PI > 1, then the project should be accepted;

- $\quad$ If $\mathrm{PI}<1$, then the project should be rejected;

- If PI = 1, the project will bring neither profit nor loss. It is obvious that the PI criterion is fully consistent with the NPV criterion in the evaluation of projects with the same initial investment.

As such, the PI criterion has an advantage in the selection of a project from a series with approximately the same NPV values but different volumes of the required investments. In this case, the project that provides greater investment efficiency is more profitable. In this regard, this indicator allows to rank projects with limited investment resources.

The disadvantages of the method include its ambiguity when discounting cash inflows and outflows separately.

\section{IRR}

The internal rate of return on investment (IRR) is understood as the value of the discount rate at which the NPV of the project is zero.

The idea of this ratio when analyzing the effectiveness of the planned investments is as follows: the IRR indicates the maximum allowable relative level of expenses that can be associated with this project. For example, if the project is fully funded by a commercial bank loan, then the IRR value indicates the upper limit of the acceptable level of the bank interest rate, which, if exceeded, makes the project unprofitable.

\section{RESULTS}

\section{Payback Period}

The PP of investments or an investment project is a ratio that indicates the period after which the initial investments (costs) in the investment project will be paid off. The economic meaning of this indicator is to define the period after which the investor will return back their invested money (capital).

$$
P P=\min n, \text { at which } \sum_{i=1}^{n} C F i>I C ;
$$

Where: IC (invested capital) is the investment capital, the initial costs of the investor. In foreign practice, the concept of the cost of capital (CC) rather than of the investment capital is sometimes used in the formula, which actually has a similar meaning; and

CF (cash flow) is a cash flow created by the object of investment. The cash flow sometimes means net profit (NP) in formulas (Table 1). 
Table 1: Payback Period

\begin{tabular}{|c|c|c|}
\hline Period (Month), T & Initial Costs, IC & Accumulated Cash Flow, CF \\
\hline 1 & 130,000 & 25,000 \\
\hline 2 & 130,000 & 50,000 \\
\hline 3 & 130,000 & 75,000 \\
\hline 4 & 130,000 & 100,000 \\
\hline 5 & 130,000 & 125,000 \\
\hline 6 & 130,000 & 150,000 \\
\hline 7 & 130,000 & 175,000 \\
\hline 8 & 130,000 & 200,000 \\
\hline PP =3 & \multicolumn{2}{|c}{} \\
\hline
\end{tabular}

The PP indicator is used as a comparative indicator to assess the effectiveness of alternative investment projects. The project with a shorter payback period is more effective. This ratio is usually used in conjunction with other indicators, in the forecast and the plan, respectively [23, 24]. Continuous improvement is of little value and may even damage, once a good forecasting process has been implement (procedures, methods, models, and management oversight).

The disadvantage of this ratio is obvious - a constant cash flow is used in its calculation. In the real conditions, it is quite difficult to forecast sustainable cash receipts in the future, thus, the payback period can change significantly. In order to reduce possible deviations from the payback plan, the reliability of the cash flow sources for the investment project should be ensured. In addition, the indicator does not account for the effect of inflation on the change in the value of money over time. The payback period of investments can be used as a screening criterion at the first stage of the assessment and selection of "heavy" investment projects $[25,26]$.

The return on investments or an investment project (accounting rate of return, return on investment, ARR, ROI) is an indicator that reflects the return on the object of investment without discounting.

$\mathrm{ARR}=\mathrm{CFav} / \mathrm{IC}$

Where: CFav is the average cash flow (net profit) of the object of investment for the period under study (month, year); and

IC (invested capital) is the investment capital, the initial costs of the investor.

This indicator is used to compare various alternative investment projects. The higher the ARR is, the higher the attractiveness of this project for an investor will be. As a rule, this indicator is used to evaluate the existing projects, where the effectiveness of creating the cash flow of a given investment can be tracked and statistically evaluated (Table 2).

Table 2: Return on Investment

\begin{tabular}{|c|c|c|}
\hline Period (Month), T & Initial Costs, IC & Cash Flow, CF \\
\hline 1 & \multirow{8}{*}{130,000} & 25,000 \\
\hline 2 & & 35,000 \\
\hline 3 & & 40,000 \\
\hline 4 & & 28,000 \\
\hline 5 & & 33,000 \\
\hline 6 & & 45,000 \\
\hline 7 & & 55,000 \\
\hline 8 & & 30,000 \\
\hline $\mathrm{ARR}=$ & \multicolumn{2}{|c|}{$28 \%$} \\
\hline
\end{tabular}


The NPV is an indicator that reflects changes in cash flows and indicates the difference between the discounted cash flows and investments.

$$
\begin{aligned}
& \mathrm{NPV}=\mathbf{k} \\
& \Sigma \mathrm{CF}_{\mathrm{t}} /(\mathbf{1}+\mathbf{r})^{\mathrm{t}}-\mathrm{CF}_{0}
\end{aligned}
$$

$\mathbf{t}=\mathbf{1}$

Where: NPV is the net present value of the project;

$\mathrm{CF}_{\mathrm{t}}$ is the cash flow over time $\mathrm{t}$;

$\mathrm{CF}_{0}$ is the cash flow at the initial moment. The initial cash flow equals the investment capital $\left(\mathrm{CF}_{0}=\mathrm{IC}\right)$;

IC is the invested capital; and

$\mathrm{r}$ is the discount rate (barrier rate) (Table 3).

\begin{tabular}{|c|c|c|c|c|}
\hline Period (Year), $\mathbf{T}$ & Initial Costs, IC & Cash Flow, CF & Discount Rate & Discounted Cash Flow \\
\hline 1 & \multirow{9}{*}{130,000} & 25,000 & \multirow{10}{*}{$10 \%$} & $22,727.27273$ \\
\hline 2 & & 27,000 & & $22,314.04959$ \\
\hline 3 & & 17,000 & & $12,772.35162$ \\
\hline 4 & & 35,000 & & $23,905.47094$ \\
\hline 5 & & 33,000 & & $20,490.40366$ \\
\hline 6 & & 29,000 & & $16,369.74397$ \\
\hline 7 & & 37,000 & & $18,986.85037$ \\
\hline 8 & & 40,000 & & $18,660.29521$ \\
\hline 9 & & 31,000 & & $13,147.02617$ \\
\hline \multicolumn{3}{|c|}{$\mathrm{NPV}=$} & & $39,373.46425$ \\
\hline
\end{tabular}

Table 3: Net Present Value

The IRR indicates a discount rate at which the NPV is equal to zero.

$0=\sum \frac{\mathbf{C F}_{\mathbf{t}}}{(1+\text { IRR })^{\mathbf{t}}}-\mathbf{C I}$

$\mathrm{CF}$ (cash flow) is the cash flow generated by the object of investment;

IRR is the internal rate of return; and

CI is the investment capital (Table 4).

\begin{tabular}{|c|c|c|}
\hline Period (Year), T & Initial Costs, IC & Cash Flow, CF \\
\hline 0 & \multirow{10}{*}{130,000} & $-130,000$ \\
\hline 1 & & 20,000 \\
\hline 2 & & 27,000 \\
\hline 3 & & 17,000 \\
\hline 4 & & 35,000 \\
\hline 5 & & 33,000 \\
\hline 6 & & 29,000 \\
\hline 7 & & 37,000 \\
\hline 8 & & 40,000 \\
\hline 9 & & 31,000 \\
\hline \multicolumn{2}{|c|}{$\mathrm{IRR}=$} & $16 \%$ \\
\hline
\end{tabular}

Table 4: Internal Rate of Return 
The PI is the indicator of investment effectiveness, which indicates the return (profitability) on the invested capital. The PI is the ratio of the discounted value of the future cash flows to the value of the initial investment. The economic meaning of this ratio is the assessment of value added for each invested ruble.

$$
\mathrm{PI}=\mathrm{NPV} / \mathrm{IC}
$$

Where: NPV is the net present value; and

IC is the invested capital (Table 5).

Table 5: Profitability Index

\begin{tabular}{|c|c|c|c|c|}
\hline Period (Year), $\mathbf{T}$ & Initial Costs, IC & Cash Flow, CF & Discount Rate & Discounted Cash Flow \\
\hline 1 & \multirow{9}{*}{130,000} & 25,000 & \multirow{9}{*}{$10 \%$} & $22,727.27273$ \\
\hline 2 & & 27,000 & & $22,314.04959$ \\
\hline 3 & & 17,000 & & $12,772.35162$ \\
\hline 4 & & 35,000 & & $23,905.47094$ \\
\hline 5 & & 33,000 & & $20,490.40366$ \\
\hline 6 & & 29,000 & & $16,369.74397$ \\
\hline 7 & & 37,000 & & $18,986.85037$ \\
\hline 8 & & 40,000 & & $18,660.29521$ \\
\hline 9 & & 31,000 & & $13,147.02617$ \\
\hline & & & $\mathrm{NPV}=$ & $39,373.46425$ \\
\hline & & & $\mathrm{PI}=$ & 0.302872802 \\
\hline
\end{tabular}

\section{CONCLUSIONS}

In conclusion, it can be confidently stated that the use of the ratios for the investment project assessment allows selecting the most attractive objects for investment. The authors have examined both statistical and dynamic assessment methods in practice: the former are suitable for reflecting the general characteristics of an object, while the dynamic ones allow for a more accurate estimation of investment parameters. In addition to external factors, internal ones also influence the assessment due to the difficulty to accurately determine the future cash receipts from the project. The indicators provide to a more extent financial description of investments and do not disclose causal relationships with the obtained income.

\section{REFERENCES}

1. Serikbaeva, G.G., Bektanov, B., Bekturganova, A. Sources of Attracting Investments in Technological Innovation Projects to Ensure the Sustainable Development of Rural Areas. Journal of Environmental Management and Tourism 10(4) (2019) 935941.

2. Madiyev, G., Kerimova, U., Yespolov, A., Bekbossynova, A., Rakhimzhanova, G. Fostering Investment-Innovative Activity within the Agro-Industrial Complex of the Republic of Kazakhstan. Journal of Environmental Management and Tourism 9(3) (2018) 533-541.

3. Vasantha, S. "Challenges of self help group members towards income generation activity." International Journal of Accounting and Financial Management Research 4.2 (2014): 1-8.

4. Kaldiyarov, D.A., Kassymova, A.M., Mussina, T.S., Korabayeva, N.B., Berkinbayeva, Y.E. An Investigation into the Scientific Methodological Foundations of Transportation Infrastructure in the Tourism Industry. Journal of Environmental Management and Tourism 8(8) (2017) 1529-1533. 
5. Parkhomenko, R.Z. Sistemnyy podkhod k upravleniyu ekonomikoy [Systematic approach to managing the economy]. Mysl, Moscow, 1997.

6. Totala, Sunita. "Investment Preferences of Salaried Persons of Indore." International Journal of Economics, Commerce and Research (IJECR) 6.2 (2016).

7. Damodaran, A. Investitsionnaya otsenka: Instrumenty i metody otsenki lyubykh aktivov [Investment assessment: Tools and methods for valuing any assets]. Transl. from English, Separate edition. Alpina Publisher, Moscow, 2017.

8. Krylov, E.I., Vlasova, V.M., Zhuravkova, I.V. Analiz effektivnosti investitsionnoy i innovatsionnoy deyatelnosti [Analyzing the effectiveness of investment and innovation activities]: Study guide. 2nd edition. Finance and Statistics, Moscow, 2003.

9. AJAEGBU, CHARLES CHIDOZIE. "Optimizing the Benefits of Foreign Direct Investment (FDI) into Uganda: The Case for Regulation or Supervision." International Journal of Accounting and Financial Management 6.2 (2016): 1-20.

10. Konstantinov, A. Portfelnoye investirovaniye na rossiyskom rynke aktsiy [Portfolio investment in the Russian stock market]. Financier 8 (2013) 28-31.

11. Shapkin, A.S., Shapkin, V.A. Ekonomicheskiye i finansovyye riski. Otsenka, upravleniye, portfel investitsiy [Economic and financial risks. Assessment, management, investment portfolio]. 9th ed. Publishing and trading company "Dashkov and Co.", Moscow, 2013.

12. Melnik, M.M. Ekonomiko-matematicheskiye metody $i$ modeli v planirovanii $i$ upravlenii finansirovaniyem [Economic and mathematical methods and models in planning and financial management]. Textbook. Higher school, Moscow, 2007.

13. Hassan, R. B., and A. S. Bello. "The Concept of Mudarabah Investment Deposits." International Journal of Business Management and Research (IJBMR) 4.2 (2014): 63-74.

14. McConnell, C.R., Brue, S.L. Economics: Principles, Problems, and Policies. Two volumes: Transl. from English. Republic, Moscow, 2009.

15. Kiseleva, I.A., Simonovich, N.E. Osobennosti Otsenki Riskov i Rol Motivatsii v Period Krizisa [Specifics of Risk Assessment and the Role of Motivation during the Crisis]. New reality, Moscow, 2016.

16. Misakov, A.V., Molamusov, Z.Kh., Misakov, V.S. Nekotoryye Metody Modelirovaniya Investitsionnoy Deyatelnosti Promyshlennykh Predpriyatiy v Usloviyakh Neopredelennosti [Some Methods of Modeling the Investment Activities of Industrial Enterprises in the Context of Uncertainty]. Economics and entrepreneurship 1-2(66) (2016) 606-610.

17. Barkin, D.E. Modelirovaniye Investitsionnoy Deyatelnosti Malogo Predpriyatiya [Modeling of the Investment Activities of a Small Enterprise]. Society. Environment. Development 1(18) (2011) 38-41.

18. Frolova, V.V. Metodika otsenki kachestva upravleniya investitsionnoy deyatelnostyu strakhovoy kompanii [Method for assessing the quality of investment management of an insurance company]. Financial analytics: problems and solutions 1(139) (2013) 26-32.

19. Vlasov, A. Risk-menedzhment: sistema upravleniya potentsialnymi poteryami [Risk management: a system for managing potential losses]. Business 5 (2013) 25-32.

20. Gitman, L.J., Joehnk, M.D. Fundamentals of investing. Pearson, London, 2004.

21. Rostova, E.P. Pokazateli otsenki effektivnosti vlozheniy $v$ bezopasnost predpriyatiya [Indicators for evaluating the effectiveness of investments in the enterprise security]. Production organizer 3(58) (2013) 68-72. 
22. Avdiyskiy, V.I. Risk-menedzhment kak sostavnaya chast korporativnoy sistemy upravleniya [Risk management as an integral part of the corporate management system]. Accounting 8 (2012) 98-101.

23. Kiseleva, I.A., Kuznetsov, V.I., Sadovnikova, N.A., Chernysheva, E.N., Androshina, I.S. Mathematical Modeling of Investment Risks. International Journal of Innovative Technology and Exploring Engineering 8(7) (2019) 2376-2379.

24. Kosov, M.E., Akhmadeev, R.G., Bykanova, O.A., Osipov, V.S., Ekimova, K.V., Frumina, S.V. Economic Practicability Substantiation of Financial Instrument Choice. Journal of Applied Economic Sciences 11(8) (2016) 1613-1623.

25. Khrustalyov, E.Yu., Slavyanov, A.S. Problemy Formirovaniya Investitsionnoy Strategii Innovatsionno-Oriyentirovannogo Ekonomicheskogo Rosta [Formation Problems of an Investment Strategy in Innovation-Oriented Economic Growth]. Forecasting problems 3(126) (2011) 19-30.

26. Mikhailovsky, A.A., Melekhin, E.S., Novoselova, I.Y. Integrated ranking of investment projects for development of uranium mines. Gornyi Zhurnal 9 (2019) 83-88. DOI: 10.17580/gzh.2019.09.11

27. Morrow, J.L., Sirmon, D.G., Hitt, M.A., Holcomb, T.R. Creating Value in the Face of Declining Performance: Firm Strategies and Organizational Recovery. Strategic Management Journal 8(3) (2007) 271-283.

28. Foss, N.J. Scientific Progress in Strategic Management: The Case of the Resource-Based View. International Journal of Learning and Intellectual Capital 4(1/2) (2007) 29-46.

29. Gaynanov, D.A., Sayfullina, L.D. Upravleniye Razvitiyem Predpriyatiya na Osnove Modelirovaniya Investitsionnoy Deyatelnosti [The Management of Enterprise Development on the Basis of Modeling Investment Activity]. Bulletin of the Ufa State Aviation Technical University 12(3) (2009) 79-87.

30. Shapkin, A.S., Shapkin, V.A. Teoriya riska i modelirovaniye riskovykh situatsiy [Risk theory and risk modeling]: a study guide for bachelors. Publishing House: Dashkov and Co, Moscow, 2014. 

